\title{
Screening of Integrin Heterodimers Expressed Functionally on the Undifferentiated Spermatogonial Stem Cells in the Outbred ICR Mice
}

\author{
Hye Jin Park ${ }^{1}$, Jung Im Yun ${ }^{2}$, Minseok Kim ${ }^{3}$, Kimyung Choi ${ }^{4}$, Eunsong Lee ${ }^{5}$, Seung Tae Lee ${ }^{1,2,6}$ \\ ${ }^{1}$ Department of Animal Life Science, Kangwon National University, Chuncheon, Korea \\ ${ }^{2}$ KustoGen Inc., Chuncheon, Korea \\ ${ }^{3}$ Department of Animal Science, Chonnam National University, Gwangju, Korea \\ ${ }^{4}$ Optipharm Inc., Cheongju, Korea \\ ${ }^{5}$ College of Veterinary Medicine, Kangwon National University, Chuncheon, Korea \\ ${ }^{6}$ Department of Applied Animal Science, Kangwon National University, Chuncheon, Korea
}

Background and Objectives: Outbred mice are widely used in toxicology, pharmacology, and fundamental biomedical research. However, there have been no reports of in vitro culture systems for spermatogonial stem cells (SSCs) derived from these mice.

Methods: As a step towards constructing a non-cellular niche supporting the in vitro maintenance of outbred mouse SSC self-renewal, we systematically investigated the types of integrin heterodimers that are expressed transcriptionally, translationally, and functionally in SSCs derived from Imprinting Control Region (ICR) mice.

Results: Among the genes encoding 25 integrin subunits, integrin $\alpha_{1}, \alpha_{5}, \alpha_{6}, \alpha_{9}, \alpha_{\mathrm{V}}$, and $\alpha_{\mathrm{E}}$, and integrin $\beta_{1}$ and $\beta_{5}$ had significantly higher transcriptional levels than the other subunits. Furthermore, at the translational level, integrin $\alpha_{5}, \alpha_{6}, \alpha_{9}, \alpha_{\mathrm{V}}, \alpha_{\mathrm{E}}$, and $\beta_{1}$ were localized on the surface of SSCs, but integrin $\alpha_{1}$ and $\beta_{5}$ not. Moreover, significantly stronger translational expression than integrin $\alpha_{9}$ and $\alpha_{\mathrm{E}}$ was observed in integrin $\alpha_{5}, \alpha_{6}, \alpha_{\mathrm{V}}$, and $\beta_{1}$. SSCs showed significantly increased adhesion to fibronectin, laminin, tenascin $\mathrm{C}$ and vitronectin, and functional blocking of integrin $\alpha_{5} \beta_{1}, \alpha_{6} \beta_{1}, \alpha_{9} \beta_{1}$ or $\alpha_{\mathrm{V}} \beta_{1}$ significantly inhibited adhesion to these molecules.

Conclusions: We confirmed that integrin $\alpha_{5} \beta_{1}, \alpha_{6} \beta_{1}, \alpha_{9} \beta_{1}$ and $\alpha_{\mathrm{V}} \beta_{1}$ actively function on the surface of undifferentiated SSCs derived from outbred ICR mice.

Keywords: Spermatogonial stem cells, Undifferentiation, Integrin, Outbred, Mouse

Received: April 11, 2020, Revised: June 9, 2020,

Accepted: July 15, 2020, Published online: August 31, 2020

Correspondence to Seung Tae Lee

Department of Applied Animal Science, Kangwon National University, Dongsangdae 2-\#105-1, Chuncheon 24341, Korea

Tel: +82-33-250-8638, Fax: +82-33-251-7719

E-mail: stlee76@kangwon.ac.kr

(c) This is an open-access article distributed under the terms of the Creative Commons Attribution Non-Commercial License (http://creativecommons.org/ licenses/by-nc/4.0/), which permits unrestricted non-commercial use, distribution, and reproduction in any medium, provided the original work is properly cited.

Copyright (c) 2020 by the Korean Society for Stem Cell Research

\section{Introduction}

The special characteristics of stem cells (i.e., self-renewal capacity and pluripotency) that allow them to differentiate into any of three germ layer lineages $(1,2)$ can be regulated by a unique microenvironment called the stem cell niche, which consists of physicochemical and physiological niches, and the extracellular matrix (ECM) $(3,4)$. To date, the defined manipulation of physicochemical and physiological niches has been limited in its ability to precisely and specifically guide the fate of stem cells $(5,6)$. Therefore, the importance of niches based on ECM has 
been emphasized as an alternative to overcoming the difficulty of regulating the fate of stem cells.

The ECM is a non-cellular three-dimensional macromolecular network composed of a variety of fibrous ECM proteins, carbohydrates, and several glycoproteins $(7,8)$, which not only provide a physical scaffold but also signals to induce cellular responses including proliferation, migration, attachment, spreading, differentiation, survival, homeostasis, and morphogenesis (9). The integrins, a group of cell adhesion molecules that exist as heterodimers with various combinations of $\alpha$ and $\beta$ subunits $(10,11)$, play pivotal roles as mediators in transporting ECM-derived signals into the cytoplasm by directly recognizing ECM components and inducing cytological changes (12). Accordingly, the combined stimulation of ECM protein-derived signals through integrin heterodimers can make it possible to accurately regulate the fate of stem cells, which requires detailed information on integrin heterodimers that are functionally expressed on the surface of stem cells.

Among the diverse stem cell types, spermatogonial stem cells (SSCs) are the only male germline stem cells that differentiate into sperm through spermatogenesis in the seminiferous tubule of the testis $(13,14)$. Their self-renewal is infinitely maintained on the seminiferous tubule basement membrane (STBM) with defined ECM components in vivo (15). Nevertheless, technical difficulties in constructing the artificial STBM has led to the use of a cellular niche based on feeder cells during the in vitro culture of SSCs (16-18). However, a small population of SSCs located in the seminiferous tubule of the testis derived from diverse species did not sufficiently expand under these conditions (19). Simultaneously, non-cellular niches using purified ECM proteins, not based on information regarding integrin heterodimers expressed in the undifferentiated SSCs also did not show efficient long-term in vitro maintenance of SSC self-renewal.

Outbred stocks of mice are widely used in toxicology, pharmacology, and fundamental biomedical research (20), although most such studies can be done much more effectively with inbred strains. Particularly, their usage in genetic studies has been very successful as a base population for selection to produce new or improved humanized mouse models (21), and for genetic fine mapping of quantitative trait loci (QTL) (22). In addition, their better breeding performance compared to inbred strains makes it easy to develop and maintain genetically modified mice (23). However, despite their usefulness, to date, there have been no reports of in vitro culture systems for SSCs derived from outbred stocks of mice.
Accordingly, as a step towards developing a precisely defined non-cellular niche engineering integrin signaling to promote self-renewal of SSCs derived from outbred mice, we examined the types of integrin heterodimers on the surface of outbred ICR mouse SSCs in the undifferentiated state. The types of integrin subunits expressed in undifferentiated SSCs were identified at the transcriptional and translational levels, and the combinations of integrin $\alpha$ and $\beta$ subunits were determined by functional assays.

\section{Materials and Methods}

\section{Animals}

Three-week-old male ICR mice were purchased from DBL (Eumseong, Korea) and used as SSC donors. All of the animal housing, handling, and experimental procedures were approved by the Institutional Animal Care and Use Committee (IACUC) of Kangwon National University (IACUC approval No. KW-130307-1) and conducted in accordance with the Animal Care and Use Guidelines of Kangwon National University.

\section{Isolation of SSC population from the testes}

The tunica albuginea and epididymis were removed from the mouse testes, and the seminiferous tubules were digested by incubation for $20 \mathrm{~min}$ in Dulbecco's Modified Eagle's Medium (DMEM; Welgene Inc., Daegu, Korea) supplemented with $0.5 \mathrm{mg} / \mathrm{ml}$ type IV collagenase (Worthington Biochemical, Lakewood, CA) at $37^{\circ} \mathrm{C}$. Subsequently, the fragmented seminiferous tubules were washed with DMEM containing $10 \%$ (v/v) heat-inactivated fetal bovine serum (FBS; Welgene), and dissociated with $0.25 \%$ trypsin-EDTA (Welgene) for $5 \mathrm{~min}$ at $37^{\circ} \mathrm{C}$. The dispersed testicular cells were filtered through a $70 \mu \mathrm{m}$ nylon strainer (SPL, Pocheon, Korea) to eliminate peritubular myoid, sertoli, and leydig cells, and the filtered testicular cells were purified by magnetic-activated cell sorting (MACS; Invitrogen, Carlsbad, CA) using anti-Thyl antibody (Novus Biologicals, Littleton, $\mathrm{CO}$ ) according to the manufacturer's instructions. Subsequently, the finally sorted cells (herein referred to as SSC population) were assigned to the following experiments.

\section{Real-time PCR}

Total mRNA was extracted from the cells using a Dynabeads mRNA Direct ${ }^{\mathrm{TM}}$ Kit (Ambion, Austin, TX), and cDNA was synthesized using ReverTra Ace qPCR RT Master Mix with gDNA remover kit (Toyobo, Osaka, Japan) in accordance with the respective manufacturer's 
instructions. Subsequently, specific gene expression was quantified with THUNDERBIRD ${ }^{\mathrm{TM}} \mathrm{SYBR}^{\mathrm{R}}$ qPCR Mix (Toyobo) using a 7500 Real-time PCR system (Applied Biosystems, Foster City, CA). PCR specificity was determined by analyzing the melting curve data. The mRNA levels are presented as $2^{-\Delta \mathrm{Ct}}$ where $\mathrm{Ct}=$ threshold cycle for target amplification and $\Delta \mathrm{Ct}=\mathrm{Ct}_{\text {target }}$ gene (specific genes for each sample) $-\mathrm{Ct}_{\text {internal reference }}(\beta$-actin for each sample). Primer sequences were designed with Primer3 software (Whitehead Institute/MIT Center for Genome Research) with mouse cDNA sequence data obtained from GenBank. General information and sequences of primers are described in Supplementary Table S1.

\section{Immunocytochemistry}

Cells fixed with $4 \%$ (v/v) paraformaldehyde (Junsei, Tokyo, Japan) for $10 \mathrm{~min}$ were washed twice with Dulbecco's phosphate-buffered saline (DPBS; Welgene). The fixed cells were stained with fluorescence-conjugated integrin $\alpha_{1}, \alpha_{5}, \alpha_{6}, \alpha_{9}, \alpha_{\mathrm{V}}, \alpha_{\mathrm{E}}, \beta_{1}$, and $\beta_{5}$ primary antibodies diluted in DPBS for $16 \mathrm{~h}$ at $4{ }^{\circ} \mathrm{C}$. After rinsing with DPBS, the stained cells were double stained by fluorescence-unconjugated glial cell line-derived neurotrophic factor (GDNF) family receptor alpha 1 (GFR $\alpha 1$; a SSC-specific marker) primary antibody diluted in DPBS, or florescence-unconjugated alpha smooth muscle actin ( $\alpha$ SMA; a peritubular myoid cell-specific marker), GATA binding protein 4 (GATA4; a sertoli cell-specific marker), or luteinizing hormone receptor (LHR; a leydig cell-specific marker) primary antibody diluted in Hank's balanced salt solution (HBSS, Invitrogen) containing $0.1 \%(\mathrm{w} / \mathrm{v})$ saponin (Sigma-Aldrich, St. Louis, MO) for $16 \mathrm{~h}$ at $4{ }^{\circ} \mathrm{C}$. Subsequently, the detection of GFR $\alpha 1$ primary antibody was conducted by incubating Alexa Fluor 488- or 546-conjugated secondary antibody diluted in DPBS for $2 \mathrm{~h}$ at $4^{\circ} \mathrm{C}$, and the detection of $\alpha$ SMA, GATA4, and LHR primary antibodies was conducted by incubating Alexa Fluor 488-, 546- or 568-conjugated secondary antibody diluted in HBSS containing $0.1 \%(\mathrm{w} / \mathrm{v})$ saponin for $1 \mathrm{~h}$ at $4{ }^{\circ} \mathrm{C}$. Supplementary Table S2 describes the detailed information and dilution rate of the used antibodies. Then, rinsing twice with DPBS was performed and the double stained cells were counterstained with mounting medium for fluorescence with 4,6-diamidino-2-phenylindole (DAPI) (Vector Laboratories, Inc., Burlingame, CA). Moreover, the triple-stained cells were monitored under a confocal laser scanning microscope (LSM880; ZEISS, Jena, Germany).

\section{Fluorescence immunoassay}

Three thousand three hundred of cells fixed in $4 \%(\mathrm{v} / \mathrm{v})$ paraformaldehyde (Junsei) for $10 \mathrm{~min}$ were rinsed twice with DPBS. Subsequently, the fixed cells were stained for $2 \mathrm{~h}$ at room temperature with FITC-conjugated anti-mouse integrin $\alpha_{5}, \alpha_{9}, \alpha_{\mathrm{V}}, \alpha_{\mathrm{E}}$, and $\beta_{1}$ and Alexa Fluor 488-conjugated anti-mouse integrin $\alpha_{6}$ antibodies diluted in DPBS. The detailed information and antibody dilutions used are listed in Supplementary Table S2. The stained cells were washed with DPBS, and fluorescence intensity was measured using SoftMax ${ }^{\circledR}$ Pro 6.2.2. (Molecular Devices Corp., Sunnyvale, CA) after adding $100 \mu 1$ DPBS to the stained cells.

\section{Attachment assay}

First, 96-well tissue culture plates were coated with the following concentrations of purified ECM proteins overnight at $4^{\circ} \mathrm{C}: 0,40$, and $80 \mu \mathrm{g} / \mathrm{ml}$ fibronectin (Millipore, Burlington, MA); 0, 200, and $400 \mu \mathrm{g} / \mathrm{ml}$ laminin (SigmaAldrich); 0, 20, and $40 \mu \mathrm{g} / \mathrm{ml}$ tenascin C (RayBiotech, Peachtree Corners, GA) and 0,5 , and $10 \mu \mathrm{g} / \mathrm{ml}$ vitronectin (R\&D Systems, Minneapolis, MN). Then, each well blocked with $1 \%(\mathrm{w} / \mathrm{v})$ bovine serum albumin (BSA; Sigma) at $4^{\circ} \mathrm{C}$ for $1 \mathrm{~h}$ was washed three times with DPBS. Aliquots of $1 \times 10^{4}$ cells were resuspended in SSC culture medium consisting of Stempro-34 medium (Invitrogen) supplemented with insulin-transferrin-selenium (ITS; Invitrogen), $60 \mu \mathrm{M}$ putrescine dihydrochloride (Sigma), $6 \mathrm{mg} / \mathrm{ml} \mathrm{D}$-(+)-glucose (Wako Pure Chemical Industries, Ltd., Osaka, Japan), $0.11 \mathrm{mg} / \mathrm{ml}$ sodium pyruvate (Sigma), $1 \mu \mathrm{l} / \mathrm{ml}$ DL-lactic acid (Sigma), $5 \mathrm{mg} / \mathrm{ml} \mathrm{BSA,} 2 \mathrm{mM}$ L-glutamine (Invitrogen), $0.05 \mathrm{mM} \beta$-mercaptoethanol (Invitrogen), 1\% (v/v) FBS, 1\% (v/v) NEAA (Invitrogen), MEM vitamin solution (Sigma), 1\% (v/v) antibiotic-antimycotic solution (Welgene), $0.1 \mathrm{mM}$ ascorbic acid (Sigma), $10^{3}$ units/ml mouse LIF (Chemicon International Inc., Temecula, CA), $10 \mathrm{ng} / \mathrm{ml}$ GDNF (R\&D systems), $30 \mathrm{ng} / \mathrm{ml}$ $\beta$-estradiol (Sigma), $60 \mathrm{ng} / \mathrm{ml}$ progesterone (Sigma), 20 $\mathrm{ng} / \mathrm{ml}$ human epidermal growth factor (EGF; Peprotech, Inc., Rocky Hill, NJ), and $10 \mathrm{ng} / \mathrm{ml}$ human basic fibroblast growth factor (bFGF; Peprotech, Inc.), and seeded in each well. After incubation at $37^{\circ} \mathrm{C}$ for $2 \mathrm{~h}$, non-adherent cells were removed by washing each well sufficiently, and adherent cells were fixed in $4 \%$ (v/v) paraformaldehyde at room temperature for $10 \mathrm{~min}$. Subsequently, the fixed adherent cells were stained with $0.1 \%(\mathrm{w} / \mathrm{v})$ crystal violet (Sigma) in 20\% (v/v) methanol (Sigma-Aldrich) for $5 \mathrm{~min}$ and washed twice with distilled water. Levels of adherent cells were quantified at $570 \mathrm{~nm}$ using a microplate reader (Epoch Microplate Spectrophotometer; BioTek 
Instruments Inc., Winooski, VT) after adding $50 \mu 1$ of $0.2 \%$ (v/v) Triton X-100 (Biopure, Cambridge, MA) diluted with distilled water.

\section{Antibody inhibition assay}

The wells of 96-well tissue culture plates were coated with $40 \mu \mathrm{g} / \mathrm{ml}$ fibronectin, $200 \mu \mathrm{g} / \mathrm{ml}$ laminin, $20 \mu \mathrm{g} / \mathrm{ml}$ tenascin $\mathrm{C}$ or $5 \mu \mathrm{g} / \mathrm{ml}$ vitronectin overnight at $4^{\circ} \mathrm{C}$, and the coated wells were blocked with $1 \%(\mathrm{w} / \mathrm{v})$ BSA for $1 \mathrm{~h}$ at $4^{\circ} \mathrm{C}$. Subsequently, to inhibit integrin function, $1 \times 10^{4}$ cells were resuspended in SSC culture medium containing anti-integrin $\alpha_{5}$ (5H10-27 [MFR5]), anti-integrin $\alpha_{6}$ (NKI-GoH3), anti-integrin $\alpha_{9}$ (Y9A2) or anti-integrin $\alpha_{\mathrm{V}}$ (RMV-7) blocking antibody, and incubated at $37^{\circ} \mathrm{C}$ for 2 h. The detailed information regarding the antibodies used is presented in Supplementary Table S2. Then, the functionally blocked cells were plated in each well and incubated at $37^{\circ} \mathrm{C}$ for $8 \mathrm{~h}$. To remove non-adherent cells, the wells were washed extensively with DPBS. The adherent cells were fixed in $4 \%(\mathrm{v} / \mathrm{v})$ paraformaldehyde for 10 min at room temperature, and staining of adherent cells was performed with $0.1 \%(\mathrm{w} / \mathrm{v})$ crystal violet in $20 \%(\mathrm{v} / \mathrm{v})$ methanol for $5 \mathrm{~min}$. Finally, the wells were washed twice with distilled water and supplemented with $50 \mu 1$ of $0.2 \%$ (v/v) Triton X-100 diluted with distilled water. The amount of dye was measured at $570 \mathrm{~nm}$ using a microplate reader.

A

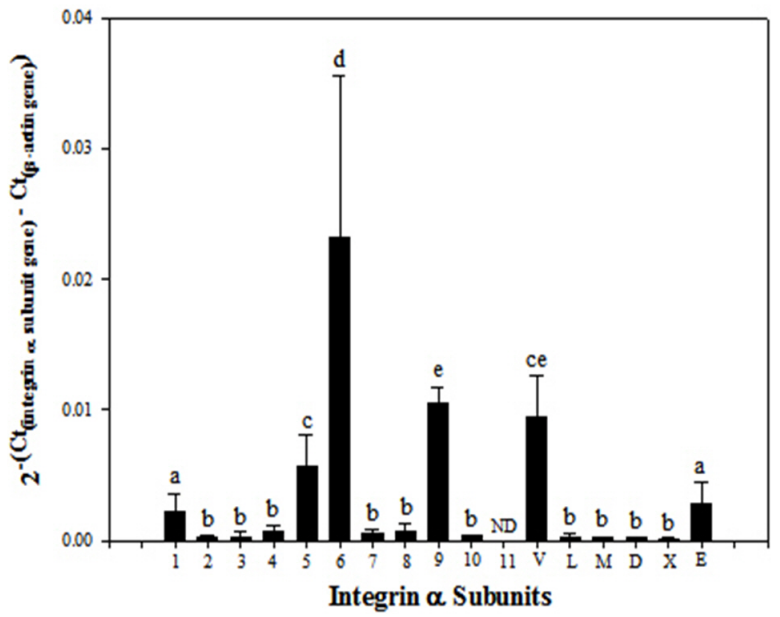

\section{Statistical analysis}

The SAS program was used for statistical analysis of the numerical data shown in each experiment. Comparisons among treatment groups were performed by the leastsquares or DUNCAN method, and the significance of the main effects was determined by analysis of variance (ANOVA) in the SAS package. In all of the analyses, $\mathrm{p}<$ 0.05 was taken to indicate statistical significance.

\section{Results}

\section{Identification of the types of cells isolated from outbred ICR mouse testes through MACS technique}

A MACS technique based on antibody detecting Thyl expressed on the surface of undifferentiated mouse SSCs did not show high yield in the isolation of undifferentiated SSCs from outbred ICR mouse testes. As shown in Supplementary Fig. S1, SSCs stained positively with GFR $\alpha 1$, peritubular myoid cells stained positively with $\alpha$ SMA, sertoli cells stained positively with GATA4, and leydig cells stained positively with LHR were detected in the retrieved SSC population post-MACS. Moreover, among four cell types included in the SSC population, SSCs $(24.57 \pm 3.12 \%)$ and peritubular myoid cells $(28.68 \pm 3.20 \%)$ showed significantly higher rate of abundance than sertoli $(16.39 \pm 1.06 \%)$ and leydig $(11.32 \pm 4.80 \%)$ cells. Therefore, in order to gain insight into the types of integrin subunit

B

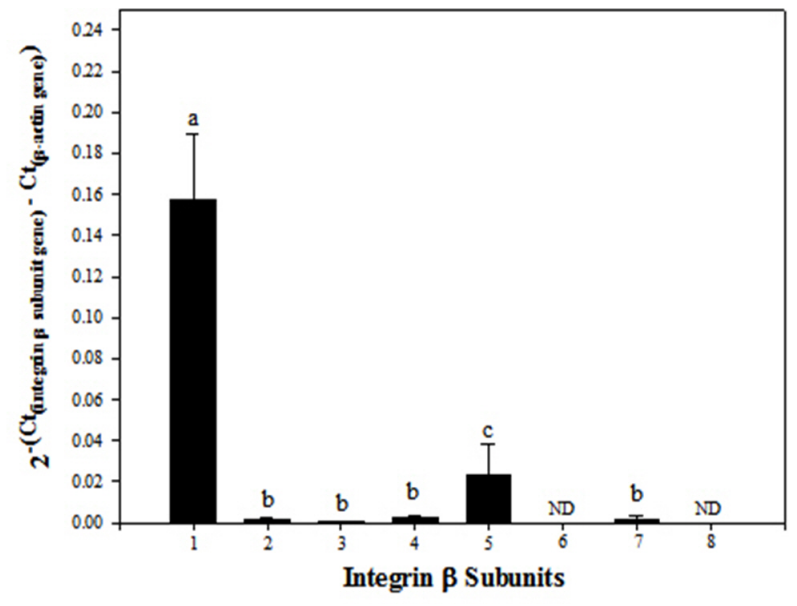

Fig. 1. Transcriptional levels of integrin $\alpha$ and $\beta$ subunit gene expression in SSC population including undifferentiated SSCs and peritubular myoid, sertoli and leydig cells derived from outbred ICR mouse testes. Testicular cells were retrieved enzymatically from testis derived from ICR mice, and the preparation of SSC population was conducted by sorting these testicular cells using a MACS technique based on anti-Thy 1 antibody. Subsequently, mRNA levels of integrin $\alpha$ and $\beta$ subunits in the isolated SSCs were examined quantitatively by real-time PCR. A total of 6 of 17 integrin $\alpha$ subunit genes $\left(\alpha_{1}, \alpha_{5}, \alpha_{6}, \alpha_{9}, \alpha_{\mathrm{V}}\right.$, and $\left.\alpha_{\mathrm{E}}\right)$ (A) and 2 of 8 integrin $\beta$ subunit genes $\left(\beta_{1}\right.$ and $\beta_{5}$ ) showed significantly increased expression (B). All data shown are means \pm standard deviation of three independent experiments. ${ }^{\mathrm{a} \sim \mathrm{e}} \mathrm{p}<0.05$. ND: not detected. 
expressed on the membrane of outbred ICR mouse SSCs in the undifferentiated state, we investigated the transcriptional levels of integrin subunit genes in the SSC population and the translation of integrin subunit genes showing significantly strong transcription were identified per each type of cells through immunocytochemistry.
Transcriptional levels of integrin subunit genes in the SSC population derived from outbred ICR mouse testes

In transcriptional analyses of genes encoding a total of 25 integrin subunits, significantly higher levels of expression were observed for integrin $\alpha_{1}, \alpha_{5}, \alpha_{6}, \alpha_{9}, \alpha_{\mathrm{V}}$, and $\alpha_{\mathrm{E}}$ (Fig. 1A), and integrin $\beta_{1}$ and $\beta_{5}$ (Fig. 1B) subunit genes. The minimum levels of expression were detected for integrin $\alpha_{2}, \alpha_{3}, \alpha_{4}, \alpha_{7}, \alpha_{8}, \alpha_{10}, \alpha_{\mathrm{L}}, \alpha_{\mathrm{M}}$, $\alpha_{\mathrm{D}}$, and $\alpha_{\mathrm{X}}$ (Fig. 1A), and integrin $\beta_{2}, \beta_{3}, \beta_{4}$, and $\beta_{7}$

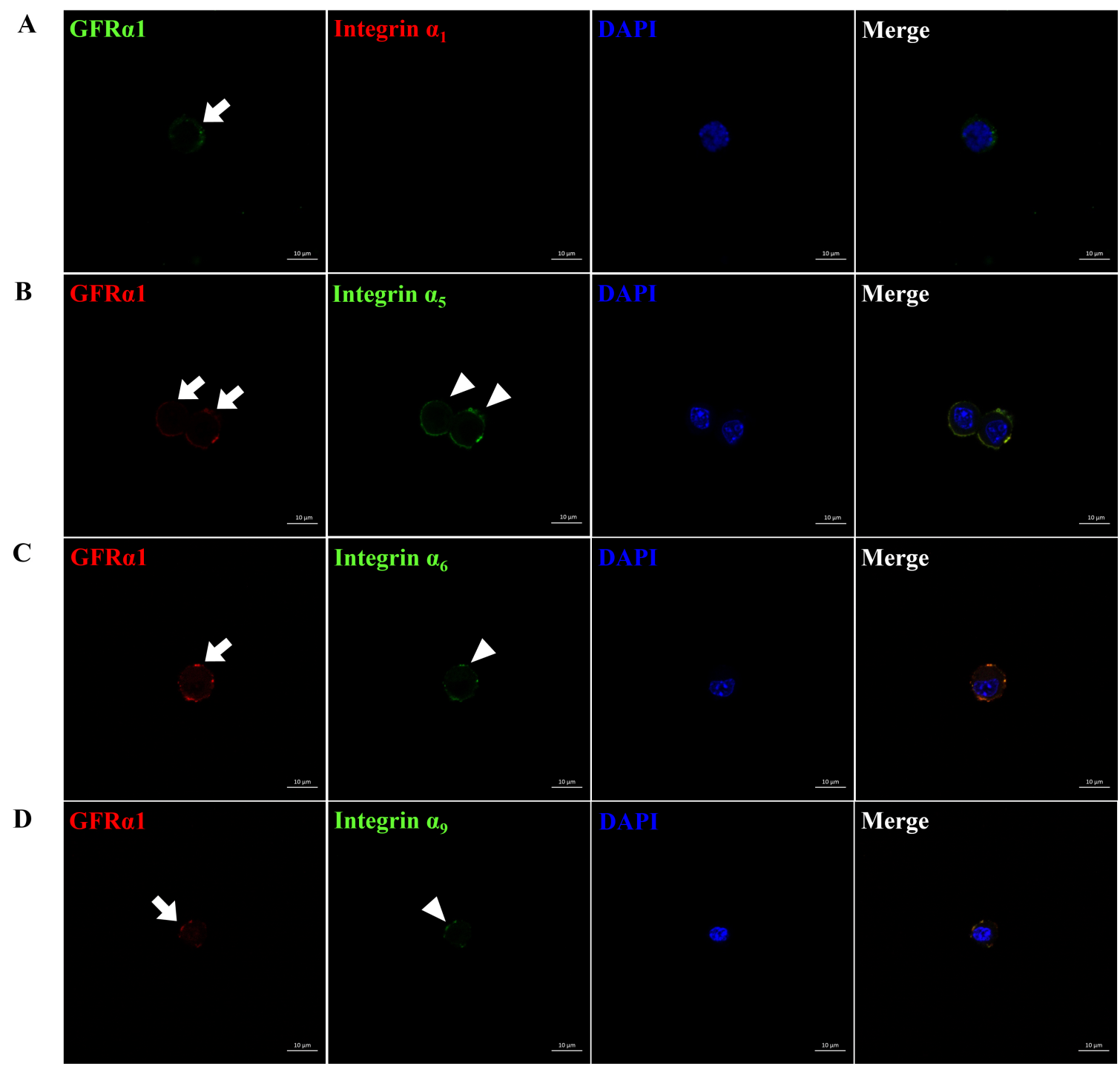

Fig. 2. Identification of integrin $\alpha$ and $\beta$ subunit proteins expressed on the surface of undifferentiated SSCs derived from outbred ICR mouse testes. To obtain testicular cells, testis derived from ICR mice was enzymatically treated and the preparation of SSC population which the proportion of SSCs in testicular cells was increased was conducted using a MACS technique based on anti-Thy 1 antibody. Subsequently, the protein expression of integrin $\alpha$ and $\beta$ subunits in the SSCs included in the sorted SSC population were identified by immunocytochemistry. As the results, integrin $\alpha_{5}, \alpha_{6}, \alpha_{9}, \alpha_{\mathrm{V}}, \alpha_{\mathrm{E}}$ and $\beta_{1}$ subunit proteins (arrow head; $\mathrm{B} \sim \mathrm{G}$ ) were localized on the surface of SSCs expressing GFR $\alpha 1$ (arrow; a SSC-specific marker), whereas any localization of integrin $\alpha_{1}$, and $\beta_{5}$ subunit proteins $(\mathrm{A}, \mathrm{H})$ was not detected on the surface of SSCs expressing GFR $\alpha 1$. All figures are representative immunocytochemistry images of integrin subunit proteins expressed on the surface of SSCs. Nuclear counterstaining was conducted using DAPI. $\mathrm{n}=3$. Scale bars represent $10 \mu \mathrm{m}$. 
$\mathbf{E}$

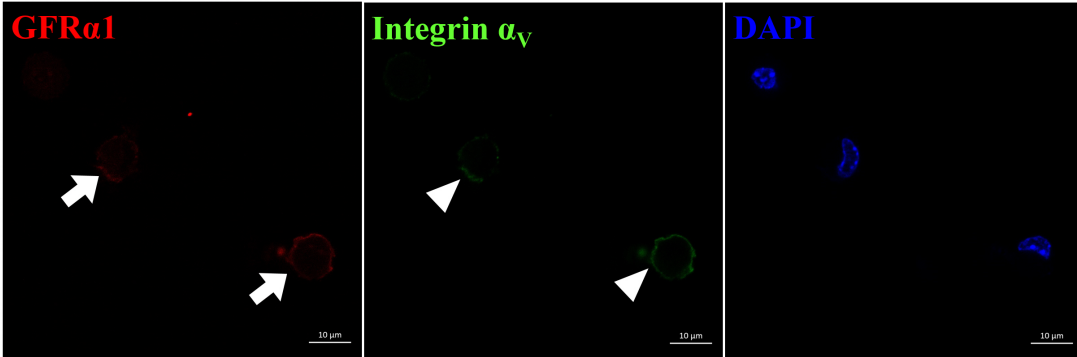

Merge

F

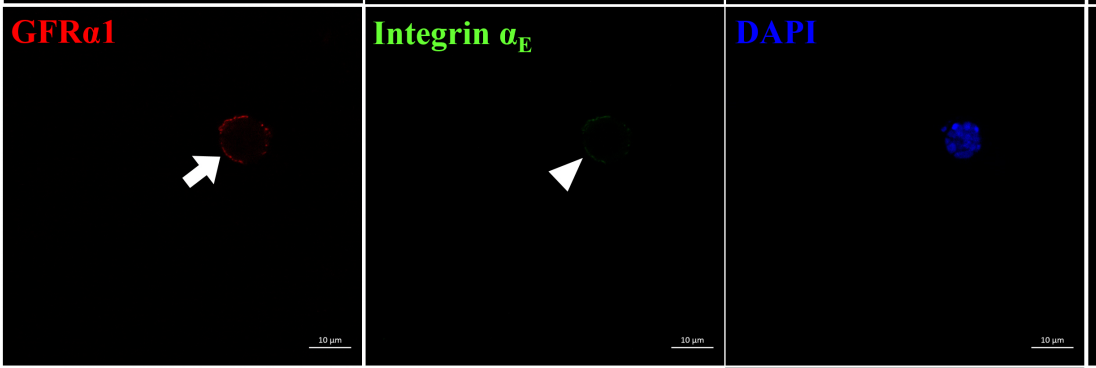

G

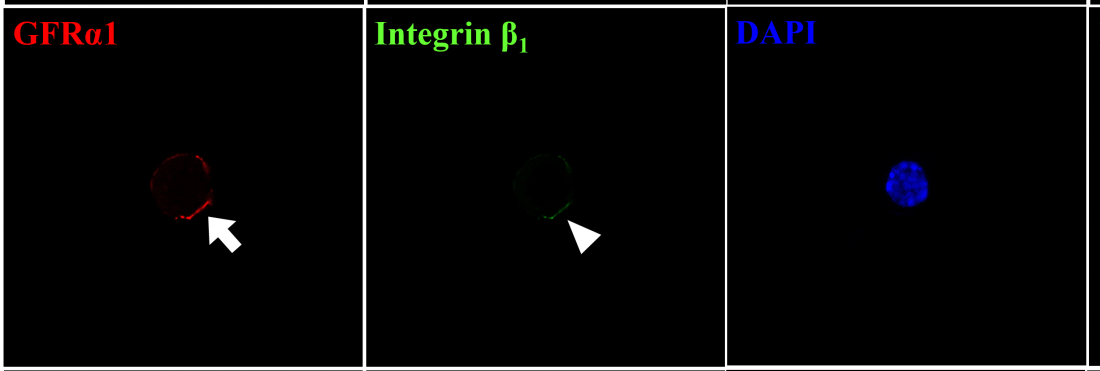

$\mathbf{H}$

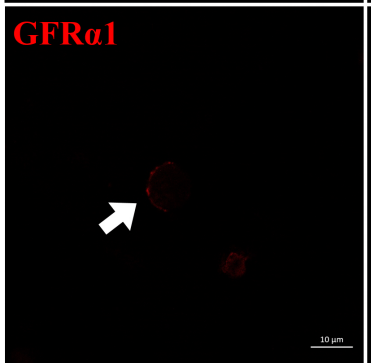

Integrin $\beta_{5}$

Merge

Fig. 2. Continued.

(Fig. 1B) subunit genes. No expression of integrin $\alpha_{11}$ (Fig. 1A) or integrin $\beta_{6}$ and $\beta_{8}$ (Fig. 1B) subunit genes was detected in these cells at the transcriptional level.

\section{Determination of integrin subunits expressed on the} membrane of undifferentiated outbred ICR mouse SSCs

Translational regulation of integrin $\alpha_{1}, \alpha_{5}, \alpha_{6}, \alpha_{9}, \alpha_{\mathrm{V}}$, and $\alpha_{\mathrm{E}}$, and integrin $\beta_{1}$ and $\beta_{5}$ subunit genes showing increased transcription was examined in each type of cells included in SSC population. As shown in Fig. 2, SSCs stained positively with GFR $\alpha 1$ showed co-localization of integrin $\alpha_{5}, \alpha_{6}, \alpha_{9}, \alpha_{\mathrm{V}}, \alpha_{\mathrm{E}}$ and $\beta_{1}$ subunit proteins on the cell surface, whereas co-localization of integrin $\alpha_{1}$ and $\beta_{5}$ subunit proteins were not detected in GFR $\alpha$ 1-positive SSCs. Furthermore, the surface of peritubular myoid (Supplementary Fig. S2), sertoli (Supplementary Fig. S3), or leydig (Supplementary Fig. S4) cells stained positively with $\alpha$ SMA, GATA4, or LHR did not show any co-localization of integrin $\alpha_{1}, \alpha_{5}, \alpha_{6}, \alpha_{9}, \alpha_{\mathrm{V}}, \alpha_{\mathrm{E}}, \beta_{1}$, and $\beta_{5}$ subunit proteins. Justly, co-localization of integrin $\alpha_{1}$ subunit protein was detected on the surface of LHR-positive leydig cells. These results demonstrate that dimerization of integrin $\alpha$ and $\beta$ subunits as active forms of integrins can't be absolutely formed on the surface of peritubular myoid, sertoli, and leydig cells, indicating the absence of their influence on the following functional assay using the retrieved SSC population postMACS.

Subsequently, levels of integrin $\alpha_{5}, \alpha_{6}, \alpha_{9}, \alpha_{\mathrm{V}}, \alpha_{\mathrm{E}}$, and $\beta_{1}$ subunit genes expressed translationally on the sur- 
face of undifferentiated SSCs s were quantified (Fig. 3). Among the six integrin subunit genes, integrin $\alpha_{\mathrm{V}}$ subunit gene had significantly the strongest translation expression, and integrin $\alpha_{5}, \alpha_{6}$, and $\beta_{1}$ subunit genes had significantly intermediate translational expression, whereas integrin $\alpha_{9}$ and $\alpha_{\mathrm{E}}$ subunit genes showed significantly very weak expression at the translational level. These results indicate that integrin $\alpha_{5}, \alpha_{6}, \alpha_{9}, \alpha_{\mathrm{V}}, \alpha_{\mathrm{E}}$ and $\beta_{1}$ subunits are presented on the surface of outbred ICR mouse SSCs in undifferentiated state.

\section{Identification of integrin heterodimers functionally expressed on the cell membrane of undifferentiated outbred ICR mouse SSCs}

Based on the results regarding integrin $\alpha$ and $\beta$ subunits expressed on the cell membrane of undifferentiated outbred ICR mouse SSCs, we speculated that these cells may possess integrin $\alpha_{5} \beta_{1}, \alpha_{6} \beta_{1}, \alpha_{9} \beta_{1}$, and $\alpha_{\mathrm{V}} \beta_{1}$ as

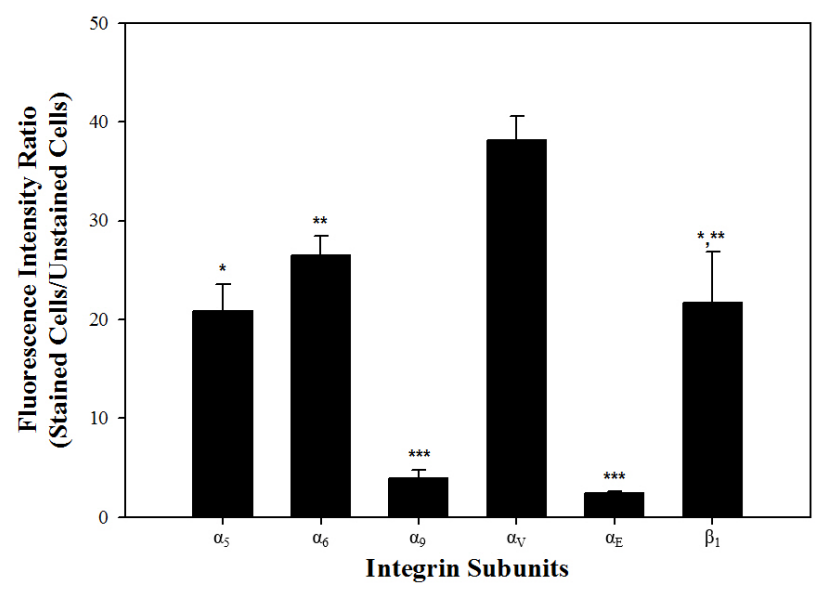

Fig. 3. Translational levels of integrin $\alpha$ and $\beta$ subunit gene expression in undifferentiated SSCs derived from outbred ICR mouse testes. In order to prepare SSC population which the proportion of SSCs in testicular cells was increased, testicular cells retrieved enzymatically from testis derived from ICR mice were sorted using a MACS technique based on anti-Thy 1 antibody. Subsequently, the protein expression levels of integrin $\alpha$ and $\beta$ subunits in the SSCs included in the sorted SSC population was analyzed by fluorescent immunoassays, and at the translational level, each integrin subunit was represented as the ratio of fluorescence intensity of stained cells to that of unstained cells. Among the six integrin subunits expressed on the surface of undifferentiated SSCs, significantly the strongest translational expression of integrin $\alpha_{v}$ subunit gene was detected, whereas integrin $\alpha_{9}$ and $\alpha_{\text {E }}$ subunit genes showed significantly the weakest expression at the translational level. Moreover, integrin $\alpha_{5}, \alpha_{6}$ and $\beta_{1}$ subunit genes showed significantly intermediate translational expression. All of the data shown are means \pm standard deviation of three independent experiments. ${ }_{-}^{*} * * * p<0.05$. active forms of integrin heterodimers as previously described (24). The presence of these integrin heterodimers was examined by estimating levels of adherent SSCs cultured on purified ECM proteins that interact specifically with each integrin heterodimer and adherent levels postculture of SSCs treated with antibodies specifically blocking each integrin function on each purified ECM protein. Fig. 4 shows significantly improved adhesion for SSCs incubated on fibronectin-, laminin-, tenascin C- and vitronectin-coated culture plates, compared to those cultured on purified ECM protein-free culture plates. These observations suggested the presence of the fibronectin-interacting integrin $\alpha_{5} \beta_{1}$, laminin-interacting integrin $\alpha_{6} \beta_{1}$, tenascin C-interacting integrin $\alpha_{9} \beta_{1}$, and vitronectin-interacting integrin $\alpha_{\mathrm{V}} \beta_{1}$ on the cell membrane of SSCs in the undifferentiated state. These specific integrin function-blocked SSCs were incubated on $40 \mu \mathrm{g} / \mathrm{ml}$ fibronectin, $200 \mu \mathrm{g} / \mathrm{ml}$ laminin, $20 \mu \mathrm{g} / \mathrm{ml}$ tenascin $\mathrm{C}$, or $5 \mu \mathrm{g} / \mathrm{ml}$ vitronectin as the minimum concentration among those seen in the ECM showing significantly improved adhesion of SSCs (Fig. 5). Significantly weakened adhesion was detected in SSCs with blockade of integrin $\alpha_{5} \beta_{1}$ (Fig. 5A), $\alpha_{6} \beta_{1}$ (Fig. 5B), $\alpha_{9} \beta_{1}$ (Fig. 5C), or $\alpha_{\mathrm{V}} \beta_{1}$ (Fig. 5D), compared to those without blocking of these integrin heterodimers. These results confirmed that the undifferentiated outbred ICR mouse SSCs simultaneously show functional expression of integrin $\alpha_{5} \beta_{1}, \alpha_{6} \beta_{1}, \alpha_{9}$ $\beta_{1}$, and $\alpha_{\mathrm{V}} \beta_{1}$ on the cell membrane.

\section{Discussion}

In constructing niches for driving the self-renewal or differentiation of SSCs, information regarding the extracellular signals in the microenvironments around undifferentiated or differentiated SSCs is essential. Particularly, extracellular signals derived from ECM proteins composing STBM that interact directly with SSCs in the seminiferous tubule (25) play an important role in determining the fate of these cells. However, intracytoplasmic transduction of these ECM-derived signals is mediated by cell-surface receptors belonging to the integrin family (26). Therefore, information on integrins present in undifferentiated or differentiated SSCs should be reflected in fabricating niches customized to each type of SSC. Here, we confirmed the types of integrin heterodimers expressed on the surface of undifferentiated SSCs from outbred ICR mice. Through transcriptional analysis of 24 integrin subunits, followed by confirmation of their expression at the translational level, attachment to ECM proteins, and inhibition with blocking antibodies, integrin 
A

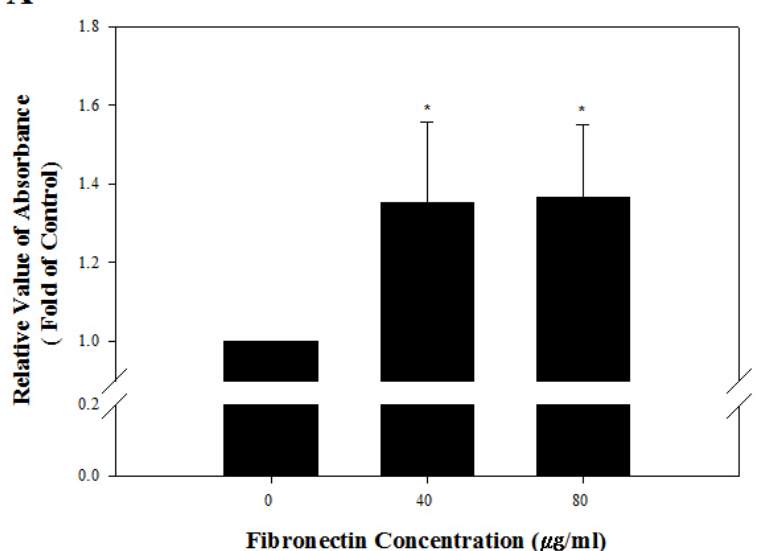

C

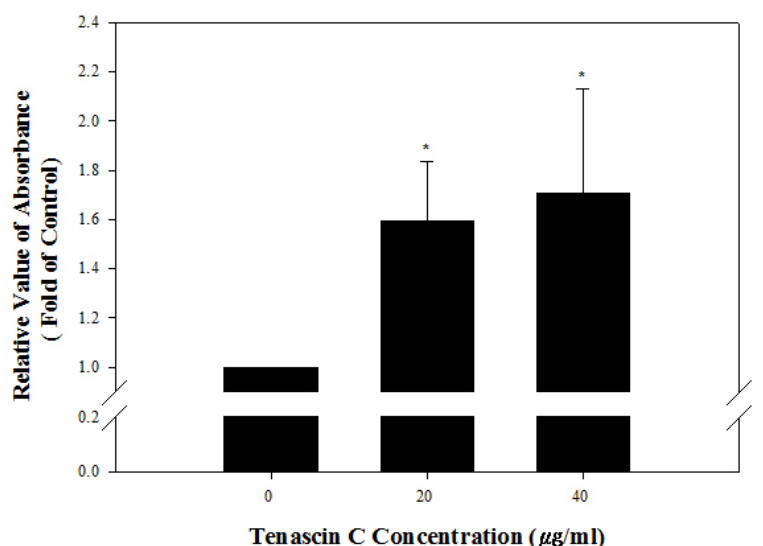

B

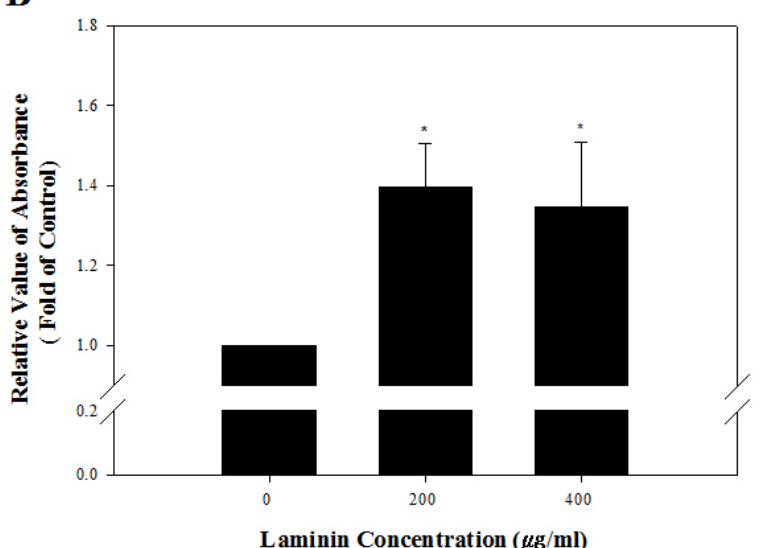

D

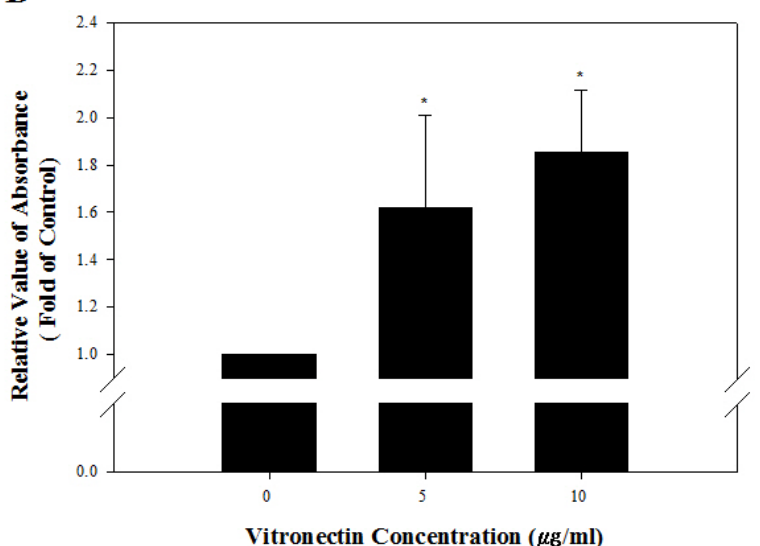

Fig. 4. Identification of the presence of integrin heterodimers interacting with fibronectin, laminin, tenascin $C$ and vitronectin on the cell membrane of undifferentiated outbred ICR mouse SSCs. A 96-well tissue culture plates was coated with 0, 40, or $80 \mu \mathrm{g} / \mathrm{ml}$ fibronectin (A), 0, 200, or $400 \mu \mathrm{g} / \mathrm{ml}$ laminin (B), 0, 20, or $40 \mu \mathrm{g} / \mathrm{ml}$ tenascin C (C), and 0, 5, or $10 \mu \mathrm{g} / \mathrm{ml}$ vitronectin (D). Subsequently, SSC population were prepared by sorting testicular cells retrieved enzymatically from testis derived from ICR mice using a MACS technique based on anti-Thy 1 antibody. Then, $1 \times 10^{4}$ cells in SSC population were resuspended in SSC culture medium and plated in each well. After incubation for $2 \mathrm{~h}$ at $37^{\circ} \mathrm{C}$, adherent cells were stained with crystal violet, and the adhesion level was quantified using a microplate reader. The percentage of maximum adhesion is represented as the optical density of cells plated on ECM protein-free plates. Mouse SSCs cultured on fibronectin-, laminin-, tenascin C- and vitronectin-coated culture plates had significantly higher levels of adhesion than those on ECM protein-free culture plates. However, increasing concentrations of ECM on the culture plates did not induce a significant improvement of mouse SSC adhesion levels. All of the data shown are means \pm standard deviation of three independent experiments. ${ }^{*} p<0.05$.

$\alpha_{5} \beta_{1}, \alpha_{6} \beta_{1}, \alpha_{9} \beta_{1}$ and $\alpha_{\mathrm{V}} \beta_{1}$ were found to be expressed on the cell membrane. These results suggest that the fibronectin-interacting integrin $\alpha_{5} \beta_{1}$, laminin-interacting integrin $\alpha_{6} \beta_{1}$, tenascin C-interacting integrin $\alpha_{9}$ $\beta_{1}$, and vitronectin-interacting integrin $\alpha_{\mathrm{V}} \beta_{1}$ may be valuable extracellular signals in maintaining outbred ICR mouse SSCs in the undifferentiated state, and that niches incorporating fibronectin, laminin, tenascin $\mathrm{C}$ and vitronectin analogs may provide support for self-renewal of SSCs derived from outbred ICR mice.

The basement membrane in the seminiferous tubule consists of fibronectin (27), laminin (28), collagen IV (29, 30 ), entactin $(31,32)$, and perlecan (33). Accordingly, the expression of integrin $\alpha_{5} \beta_{1}$ and $\alpha_{6} \beta_{1}$ on the surface of the undifferentiated outbred ICR mouse SSCs (Fig. 4, 5) suggest that fibronectin and laminin within the STBM may be key extracellular signals for maintaining the self-renewal of outbred ICR mouse SSCs. Interestingly, outbred ICR mouse SSCs also expressed integrin $\alpha_{9} \beta_{1}$ and $\alpha_{\mathrm{V}} \beta_{1}$ in the undifferentiated state (Fig. 4, 5). However, there are no tenascin $\mathrm{C}$ or vitronectin interacted with integrin $\alpha_{9} \beta_{1}$ or $\alpha_{\mathrm{V}} \beta_{1}$ within the STBM. Therefore, we speculated that the tenascin $\mathrm{C}$ - and vitronectin-derived extracellular signal may be derived from the ECM of neighboring SSCs, supporting maintenance of outbred ICR mouse SSC self-renewal by combining with extracellular 
A

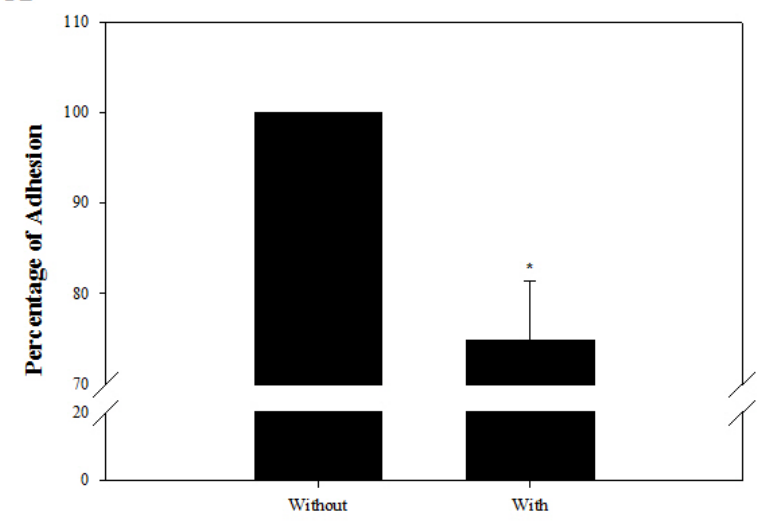

Integrin $\alpha_{5}$ Blocking Antibody

C

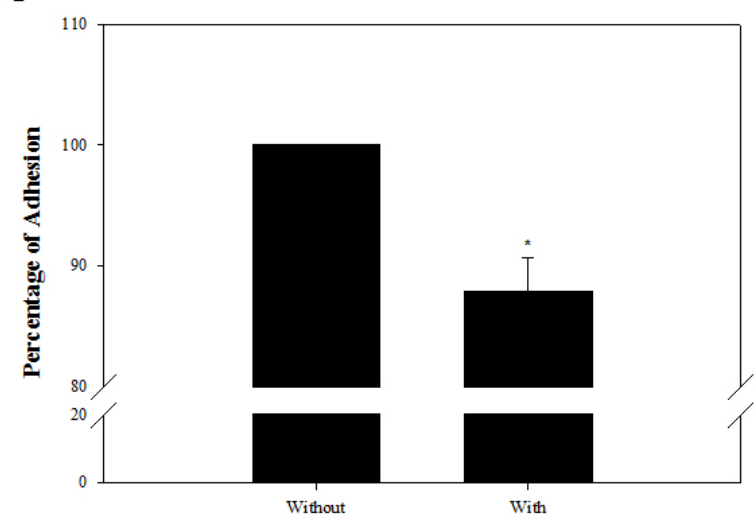

Integrin $\alpha_{9}$ Blocking Antibody
B

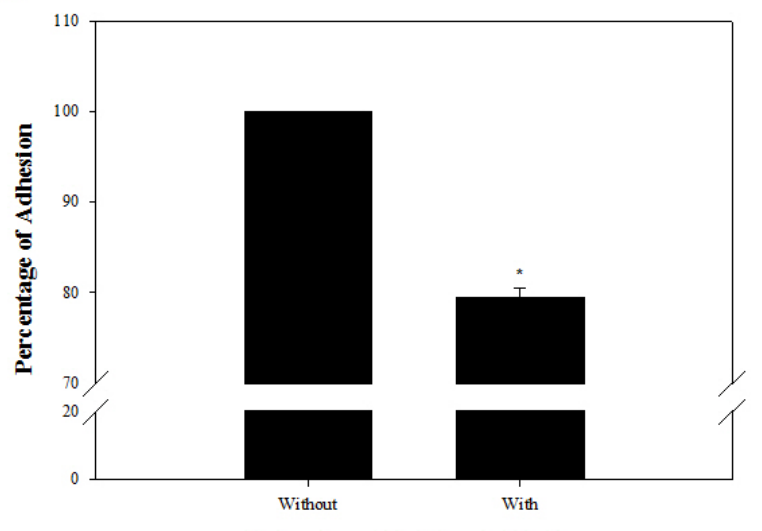

Integrin $\alpha_{6}$ Blocking Antibody

D

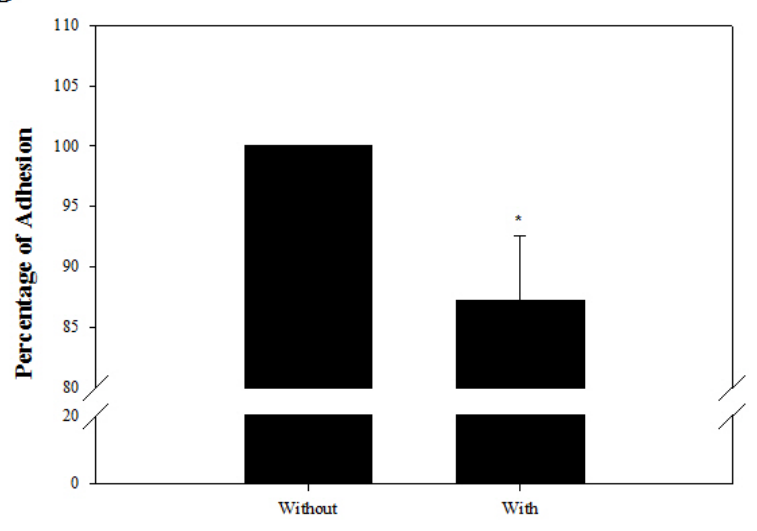

Integrin $\alpha_{\mathrm{v}}$ Blocking Antibody

Fig. 5. Functional analysis of integrin heterodimers suspected to function on the cell membrane of undifferentiated outbred ICR mouse SSCs. SSC population were prepared by sorting testicular cells retrieved enzymatically from testis derived from ICR mice using a MACS technique based on anti-Thy 1 antibody. Subsequently, $1 \times 10^{4}$ cells in SSC population were incubated in the absence or presence of anti-integrin $\alpha_{5}\left(5 \mathrm{H} 10-27\right.$ [MFR5]) (A), anti-integrin $\alpha_{6}(\mathrm{NKI}-\mathrm{GoH} 3)$ (B), anti-integrin $\alpha_{9}$ (Y9A2) (C), or anti-integrin $\alpha_{\mathrm{V}}$ (RMV-7) (D) blocking antibody, plated on $40 \mu \mathrm{g} / \mathrm{ml}$ fibronectin-, $200 \mu \mathrm{g} / \mathrm{ml}$ laminin-, $20 \mu \mathrm{g} / \mathrm{ml}$ tenascin C, and $5 \mu \mathrm{g} / \mathrm{ml}$ vitronectin-coated wells, and incubated for $8 \mathrm{~h}$ at $37^{\circ} \mathrm{C}$. After staining adherent cells with crystal violet, quantification of adhesion level was conducted using a microplate reader. As a parameter of functional blocking by antibodies, the percentage of maximum adhesion, which is represented by the optical density of cells plated on each ECM protein-coated well in the absence of any blocking antibodies, was determined. Mouse SSCs treated with integrin $\alpha_{5} \beta_{1}, \alpha_{6} \beta_{1}, \alpha_{9} \beta_{1}$, and $\alpha_{\mathrm{V}} \beta_{1}$ blocking antibodies showed significantly lower rates of attachment to each ECM component compared to mouse SSCs without blocking antibody. All of the data shown are means \pm standard deviation of three independent experiments. ${ }^{*} \mathrm{p}<0.05$.

signals derived from fibronectin and laminin within the STBM. In contrast, integrin $\alpha_{9} \beta_{1}$ and $\alpha_{\mathrm{V}} \beta_{1}$ may be an inducer of spermatogenesis due to its localization on the membrane as active heterodimers rather than inactivated subunits (Fig. 4, 5), as supported by previous reports that tenascin $\mathrm{C}$ and vitronectin is expressed in the seminiferous tubules of the adult testes showing normal spermatogenesis $(34,35)$. However, further studies are required to validate these speculations.

In conclusion, transcriptional, translational, and functional screening of integrins demonstrated the expression of integrin $\alpha_{5} \beta_{1}, \alpha_{6} \beta_{1}, \alpha_{9} \beta_{1}$ and $\alpha_{V} \beta_{1}$ on the surface of the undifferentiated SSCs derived from outbred ICR mice. The identified integrin heterodimers may be useful for maintaining mouse SSCs from outbred strains in undifferentiated state. Moreover, these achievements will greatly improve the applicability of niches with regard to the maintenance of SSC self-renewal.

\section{Acknowledgments}

This work was supported by Korea Institute of Planning and Evaluation for Technology in Food, Agriculture, 
Forestry and Fisheries (IPET) through Agri-Bioindustry Technology development Program, funded by Ministry of Agriculture, Food and Rural Affairs (MAFRA) (IPET1170 42-3).

\section{Potential Conflict of Interest}

The authors have no conflicting financial interest.

\section{Supplementary Materials}

Supplementary data including two tables and four figures can be found with this article online at http://pdf. medrang.co.kr/paper/pdf/IJSC/IJSC-13-s20061.pdf.

\section{References}

1. Liu N, Lu M, Tian X, Han Z. Molecular mechanisms involved in self-renewal and pluripotency of embryonic stem cells. J Cell Physiol 2007;211:279-286

2. Saunders A, Faiola F, Wang J. Concise review: pursuing self-renewal and pluripotency with the stem cell factor Nanog. Stem Cells 2013;31:1227-1236

3. Chen S, Lewallen M, Xie T. Adhesion in the stem cell niche: biological roles and regulation. Development 2013;140: 255-265

4. Lane SW, Williams DA, Watt FM. Modulating the stem cell niche for tissue regeneration. Nat Biotechnol 2014;32: 795-803

5. Gattazzo F, Urciuolo A, Bonaldo P. Extracellular matrix: a dynamic microenvironment for stem cell niche. Biochim Biophys Acta 2014;1840:2506-2519

6. Rompolas P, Mesa KR, Greco V. Spatial organization within a niche as a determinant of stem-cell fate. Nature 2013; 502:513-518

7. Ahn S, Lee KY, Parker KK, Shin K. Formation of multi-component extracellular matrix protein fibers. Sci Rep 2018;8:1913

8. Theocharis AD, Skandalis SS, Gialeli C, Karamanos NK. Extracellular matrix structure. Adv Drug Deliv Rev 2016; 97:4-27

9. Schaefer L, Reinhardt DP. Special issue: Extracellular matrix: therapeutic tools and targets in cancer treatment. Adv Drug Deliv Rev 2016;97:1-3

10. Bökel C, Brown NH. Integrins in development: moving on, responding to, and sticking to the extracellular matrix. Dev Cell 2002;3:311-321

11. Seguin L, Desgrosellier JS, Weis SM, Cheresh DA. Integrins and cancer: regulators of cancer stemness, metastasis, and drug resistance. Trends Cell Biol 2015;25:234240

12. Vecino E, Heller JP, Veiga-Crespo P, Martin KR, Fawcett JW. Influence of extracellular matrix components on the expression of integrins and regeneration of adult retinal ganglion cells. PLoS One 2015;10:e125250
13. Guan K, Nayernia K, Maier LS, Wagner S, Dressel R, Lee JH, Nolte J, Wolf F, Li M, Engel W, Hasenfuss G. Pluripotency of spermatogonial stem cells from adult mouse testis. Nature 2006;440:1199-1203

14. Lovasco LA, Gustafson EA, Seymour KA, de Rooij DG, Freiman RN. TAF4b is required for mouse spermatogonial stem cell development. Stem Cells 2015;33:1267-1276

15. Takashima S, Kanatsu-Shinohara M, Tanaka T, Morimoto $\mathrm{H}$, Inoue $\mathrm{K}$, Ogonuki $\mathrm{N}$, Jijiwa $M$, Takahashi M, Ogura A, Shinohara T. Functional differences between GDNF-dependent and FGF2-dependent mouse spermatogonial stem cell self-renewal. Stem Cell Reports 2015;4:489-502

16. Han NR, Park YH, Yun JI, Park HJ, Park MH, Kim MS, Choi JH, Lee E, Gong SP, Lim JM, Lee ST. Determination of feeder cell-based cellular niches supporting the colonization and maintenance of spermatogonial stem cells from prepubertal domestic cat testes. Reprod Domest Anim 2014;49:705-710

17. Lee KH, Lee WY, Kim JH, Park CK, Do JT, Kim JH, Choi YS, Kim NH, Song H. Subculture of germ cell-derived colonies with GATA4-positive feeder cells from neonatal pig testes. Stem Cells Int 2016;2016:6029271

18. Park MH, Park JE, Kim MS, Lee KY, Yun JI, Choi JH, Lee E, Lee ST. Identification of niche conditions supporting short-term culture of spermatogonial stem cells derived from porcine neonatal testis. J Emb Trans 2014;29:221-228

19. He BR, Lu F, Zhang L, Hao DJ, Yang H. An alternative long-term culture system for highly-pure mouse spermatogonial stem cells. J Cell Physiol 2015;230:1365-1375

20. Yalcin B, Nicod J, Bhomra A, Davidson S, Cleak J, Farinelli L, Østerås M, Whitley A, Yuan W, Gan X, Goodson M, Klenerman P, Satpathy A, Mathis D, Benoist C, Adams DJ, Mott R, Flint J. Commercially available outbred mice for genome-wide association studies. PLoS Genet 2010;6:e1001085

21. Aldinger KA, Sokoloff G, Rosenberg DM, Palmer AA, Millen KJ. Genetic variation and population substructure in outbred CD-1 mice: implications for genome-wide association studies. PLoS One 2009;4:e4729

22. Gatti DM, Svenson KL, Shabalin A, Wu LY, Valdar W, Simecek P, Goodwin N, Cheng R, Pomp D, Palmer A, Chesler EJ, Broman KW, Churchill GA. Quantitative trait locus mapping methods for diversity outbred mice. G3 (Bethesda) 2014;4:1623-1633

23. Chia R, Achilli F, Festing MF, Fisher EM. The origins and uses of mouse outbred stocks. Nat Genet 2005;37:1181-1186

24. Hynes RO. Integrins: versatility, modulation, and signaling in cell adhesion. Cell 1992;69:11-25

25. Meistrich ML, Shetty G. The new director of "the spermatogonial niche": introducing the peritubular macrophage. Cell Rep 2015;12:1069-1070

26. Schwartz MA. Integrins and extracellular matrix in mechanotransduction. Cold Spring Harb Perspect Biol 2010;2: a005066

27. Baert Y, Stukenborg JB, Landreh M, De Kock J, Jörnvall H, Söder O, Goossens E. Derivation and characterization 
of a cytocompatible scaffold from human testis. Hum Reprod 2015;30:256-267

28. Yan HH, Cheng CY. Laminin alpha 3 forms a complex with beta3 and gamma3 chains that serves as the ligand for alpha 6betal-integrin at the apical ectoplasmic specialization in adult rat testes. J Biol Chem 2006;281:1728617303

29. Glattauer V, Irving-Rodgers HF, Rodgers RJ, Stockwell S, Brownlee AG, Werkmeister JA, Ramshaw JA. Examination of basement membrane components associated with the bovine seminiferous tubule basal lamina. Reprod Fertil Dev 2007;19:473-481

30. Harvey SJ, Perry J, Zheng K, Chen D, Sado Y, Jefferson B, Ninomiya Y, Jacobs R, Hudson BG, Thorner PS. Sequential expression of type IV collagen networks: testis as a model and relevance to spermatogenesis. Am J Pathol 2006;168:1587-1597
31. Gersdorff N, Kohfeldt E, Sasaki T, Timpl R, Miosge N. Laminin gamma3 chain binds to nidogen and is located in murine basement membranes. J Biol Chem 2005;280:2214622153

32. Siu MK, Cheng CY. Extracellular matrix and its role in spermatogenesis. Adv Exp Med Biol 2008;636:74-91

33. Miqueloto CA, Zorn TM. Characterization and distribution of hyaluronan and the proteoglycans decorin, biglycan and perlecan in the developing embryonic mouse gonad. J Anat 2007;211:16-25

34. Nuovo GJ, Preissner KT, Bronson RA. PCR-amplified vitronectin mRNA localizes in situ to spermatocytes and round spermatids in the human testis. Hum Reprod 1995; 10:2187-2191

35. Giebel J, Löster K, Rune GM. Localization of integrin beta 1, alpha 1, alpha 5 and alpha 9 subunits in the rat testis. Int J Androl 1997;20:3-9 